\title{
Paideusis
}

\section{Care and Moral Motivation (Debra Shogan)}

\section{Andrew Blair}

Volume 3, Number 1, 1989

URI: https://id.erudit.org/iderudit/1073407ar

DOI: https://doi.org/10.7202/1073407ar

See table of contents

Publisher(s)

Canadian Philosophy of Education Society

ISSN

0838-4517 (print)

1916-0348 (digital)

Explore this journal

Cite this review

Blair, A. (1989). Review of [Care and Moral Motivation (Debra Shogan)].

Paideusis, 3(1), 20-22. https://doi.org/10.7202/1073407ar

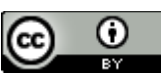

This document is protected by copyright law. Use of the services of Erudit (including reproduction) is subject to its terms and conditions, which can be viewed online.

https://apropos.erudit.org/en/users/policy-on-use/
This article is disseminated and preserved by Érudit.

Érudit is a non-profit inter-university consortium of the Université de Montréal, Université Laval, and the Université du Québec à Montréal. Its mission is to promote and disseminate research.

https://www.erudit.org/en/ 
Debra Shogan, Care and Moral Motivation (Toronto: OISE Press, 1988). 101 pages. Paperback.

In her book, Care and Moral Motivation, Debra Shogan continues a line of inquiry developed by the feminist scholars, Carol Gilligan and Nel Noddings. She identifies two aims for the book: first, to provide an account of care as moral motivation, and second, to discuss how a person can be motivated to care. She attempts to give benevolence and justice, care and principles, emotionality and rationality, connection and autonomy, and other aspects of morality which are often seen as contrasting, their due place in the life of the caring person, whether male or female. Thus, unlike Gilligan, who has tended to contrast a male ethic of justice with a female ethic of care, Shogan melds the two.

Her account makes care the heart of morality by tying caring desires closely to motivating reasons for action. Without such desires, moral reasoning is merely an intellectual exercise. Furthermore, she says, genuine moral reasons can be derived only from such desires; to give someone self-interested reasons to be moral is contradictory. Even a desire to be a virtuous person, owing to its focus on the self rather than others, cannot in itself issue genuine moral reasons.

Shogan defines two types of caring desires: benevolent desires, which are concerned with the welfare of other sentient beings, and just desires, which are concerned with fair treatment for all sentient beings in situations of conflict. A caring person is someone with fairly permanent benevolent and just desires. Usually such a person finds a sense of duty to be superfluous, for she is motivated by direct desires to see that others are treated well and fairly. Nevertheless, in some circumstances, she may find that she does not have the requisite direct desires, but, because she generally cares, will desire to act conscientiously on principles of benevolence or justice.

Shogan distinguishes between desires and emotions. Unlike desires, emotions do not motivate, but they are concomitants of desire. They are an important part of a caring response because they indicate to the recipient of care the presence of caring desires. For example, it means more to someone that another is acting out of a direct desire for their welfare than out of a sense of duty, and this will be conveyed by a properly displayed emotional response by the one caring.

A caring person is necessarily committed to moral education, Shogan argues, for if someone cares about others she will not only be concerned with how she herself treats them, but also with how others treat them. She says that moral education requires the establishment of environments in which care can be nurtured. Schools can be made into such environments though there is limit to what they can do without changes in the larger social environment.

Relying on Iris Murdoch's The Sovereignty of Good, Shogan points out that it is not possible simply to decide to be a caring person, but that caring desires can be cultivated by a process of habitual attention to the well-being and fair treatment of others. School teachers may be able to influence this process by drawing the attention of students to morally relevant features of various situations. This, however, does not require a special class in moral education, and Shogan does not appear to believe that the systematic approach of a special class would be helpful in this regard. She does acknowledge, however, that some of the adjuncts to desire in a caring response, such as the ability to under- 
stand moral situations, to reason well within them, and to perform with practical and social skill, may lend themselves more readily to a systematic approach. Special classes in ethics may have some value, she says, but they are not to be confused with moral education, which necessarily includes the development of a full-blown moral response, including its heart, caring desires.

This is an admirably orderly and clean account which makes much better sense of morality than do accounts which oppose care and justice, desire and duty, and so forth. Its neatness, however, is bought at the expense of overlooking many of the complexities of the psyche, with its complicated interconnections among motivations. Moral life is virtually never governed by pure care for others. Other motivations are mixed in, and a large part of moral development consists in learning accurately to interpret what one's real motivations are. Only through such self- understanding can one avoid the type of unconscious hypocrisy involved in thinking that one is a caring person, when what one is really motivated by is a desire to maintain a caring image. Such self-deception can be very damaging to a moral environment because of the defense mechanisms people set up to keep their self-image intact, blaming the victims of their own failure to care, and so on. In one respect Shogan's account is helpful in this regard, because it is so clear about what constitutes genuine moral motivation, but it does not attempt to be helpful in getting us to see care in relation to the overall structure of the psyche.

Duly recognized self-interested motivations are not necessarily inimical to the kind of life a caring person seeks to live. In fact, they can be harnessed in the service of care. For example, imagine a caring person who also desires to be held in high regard as a caring person. This desire is, of course, self- interested. Such a person will try to act in a caring way, even when her caring desires are not sufficient to motivate her. This has two results: one, the interests of others are served, and two, by turning her attention to the interests of others she strengthens her genuine caring desires. While Shogan elaborates on the idea of directing one's attention to the well-being of others as a method for strengthening care, nowhere does she acknowledge the possible role of self-interest as a motivation for using this method. Perhaps this is because she so definitely wants to avoid any conflation of self-interest with morality. But the idea of becoming a more caring person for selfish reasons is not such a conflation. There is nothing incoherent in the idea of having self-interested reasons to do things which will cause one to acquire caring desires.

Shogan underestimates the potential of special classes in moral education. I do not think that it matters whether they are called courses in ethics or in moral education, and I believe that she is wrong in concluding that they cannot contribute to the development of caring desires. Such courses need not be merely courses in moral reasoning. For example, they can include projects chosen by the students to promote the welfare and fair treatment of others. In addition to the actual good they could do, they could also help students to sort out how best to act on their caring desires, sort out what their real motivations are, and draw their attention to things which will give strength to their caring desires. Thus, they can utilize the very method of directing attention which Shogan offers as a way of fostering care. Furthermore, it is important to frankly encourage the harnessing of self-interested motivations in the service of benevolent and just purposes. Young people should be encouraged, for example, to choose career 
plans which serve the general welfare, but which also enable them to fuel the pursuit of these plans with self-interested motivations.

Shogan places her hope for genuine moral education on social change which will produce environments in which care can be nourished. I concur. But in order to have such change, we need people with great clarity of social insight to adopt well- organized personal projects for change. Without such insight caring desires are susceptible of being manipulated for harmful purposes. Properly designed moral education courses in public schools could do more than any other institution to aid people in acquiring such insight, and to help them organize such projects. My sense of the moral consciousness of teachers gives me the impression that a great deal of caring desire goes to waste because teachers' minds lack sufficient clarity about the nature of the moral enterprise to give them the confidence of purpose necessary to act on their caring desires. Also, schools are not designed to give them adequate opportunity to nurture care in others. This situation will not be remedied until there is a well-planned approach to the moral education of both students and their teachers. For this, the institutionalized focus which a special course would provide, is necessary.

One final remark before summing up: it pleases me that Shogan identifies exactly what the recipients of care should be - sentient beings, whether human or not. Perhaps someday there will be enough clear-sighted care to end the barbaric practice of slaughtering non-human sentient beings in order to eat their corpses and wear their skins, when this is not necessary.

In sum, Shogan succeeds in giving a succinct account of care as moral motivation, which places care in its context with other elements of the moral life, such as duty, in such a way as to make good sense of the relationship among these elements which are often thought to be at odds with each other. Her discussion of how a person can be motivated to care draws attention to an important point made by Iris Murdoch, but beyond that is too thin to be helpful in understanding this very complex question. 